\title{
马斯洛需要层次理论在企业招聘工作中的应用
}

\author{
沈蒙 \\ 中冶沈勘工程技术有限公司 \\ DOI:10.12238/ej.v3i4.491
}

\begin{abstract}
[摘 要] 随着社会经济的发展, 企业的不断转型升级, 人力资源在企业的发展中起到举足轻重的作用。企 业是否具有长远发展的动力、能否实现可持续发展, 都依赖于能否吸引和留住优秀可靠的人力资源。面 对当下日益突出的劳动力供需矛盾的发展形势, 企业管理者要用全新的思路来看待企业中最重要的资 源一人力资源。创建新时代企业人力资源管理新模式, 完善和改进每一个管理领域和管理手段的旧模 式势在必行。人力资源管理的六大模块均存在创新的可能性,如人力资源规划、招聘、薪酬福利管理、 员工教育培训开发、绩效管理、劳动关系管理。任何一项任务的开发管理理念、制度、模式、方式、 方法等都可能创新。最有效、最便捷的方式就是创新企业人力资源管理招聘工作的方式和方法,对优秀 人才形成足够大的吸引力, 巩固现有人才的激励机制,为企业建立一支高质量的人力资源队伍。
\end{abstract}

[关键词] 人力资源；招聘；创新

中图分类号: C962 文献标识码: A

企业的发展战略应该随着社会经济 发展形势进行适时地调整, 实行有效的 招聘管理工作是提高企业核心竞争力的 最佳途径。企业能否拥有优秀可靠的人 才, 关系着企业生产、管理和发展, 这些 都离不开招聘工作的有效实施。为保证 企业的发展顺应市场需求, 保证企业经 济效益不断提高, 企业必须建立起优秀 的人才储备库, 才能对企业未来的发展 做出准确部署, 适应当前社会形势的需 要。人力资源管理中的招聘工作是为企 业发展储备人才最便捷有效的方式。因 此, 创新企业人力资源管理招聘工作在 企业发展中显得尤为重要。美国社会心 理学家马斯洛认为人类需要的强度并不 都是相等的, 他将人的需要由低到高分 成五种类型, 生理需要、安全需要、归属 和爱的需要、尊重需要、自我实现的需 要, 前三个层次为基本需要, 后两个层次 为高级需要。在不同组织中、不同时期 中的不同员工的需求充满差异性, 要有 针对性地根据不同需求进行激励。在传 统招聘工作实施中, 更多的关注应聘者 “能为企业带来什么”, 在人才竞争日益 激烈的今天, 企业还应关注“能为应聘者 提供什么”。将马斯洛需要层次理论应用
于企业招聘工作的创新做出以下几方面 改进:

\section{1 建立完善的薪酬福利制度,} 满足员工安全需要

随着公司不断发展, 对高精尖人才 的吸引和留住越来越迫切, 应聘者首先 关注的就是企业的薪酬福利, 这就是员 工的安全需要。要保证在同行业间有一 定竞争优势的薪酬福利基础上体现人才 层次薪酬福利的差异性, 薪酬管理与分 配显得极为重要, 使薪酬福利与人才能 力相匹配。为充分体现薪酬分配外部公 平与内部公平性, 打破平均主义的旧观 念, 在保证职工现有薪资待遇基础上持 续深化薪酬制度改革, 价值导向型分配 改革力度将不断加大, 充分体现劳者多 得、能者多得的管理特点, 薪资标准依据 职工学历、职称、岗位贡献等条件进行 精细划分, 同时, 在原有交通补贴、取暖 补贴等薪资福利基础上增加租房补贴, 保障新员工的生活条件, 满足员工居住 的基本需要, 减少应聘者的生活压力。另 外, 改变绩效奖金原有繁琐的计算方式, 采用更直观的方法, 使绩效奖金与公司 经营业绩、经营难度、职工平均工资、 个人考核系数相挂钩, 坚持激励与约束、
短期激励与长期激励相结合, 充分调动 员工的工作热情, 从而形成足够大的吸 引力, 在持续优化公司人才结构的同时 增强员工不断进步的动力。在公司未来 发展中要持续关注收入分配结构、不断 完善和健全收入分配调节机制, 助力公 司长远发展。

2 构建良好的企业文化,提供 健康舒适的工作环境,满足员工归属 和爱的需要

企业文化是一个企业的核心和灵魂, 是企业发展的源泉和动力, 拥有良好的 企业文化能够引领企业和员工积极健康 的发展, 能够形成一种向心力, 将企业和 员工紧密联系在一起, 这样会对应聘者 形成一种无形的吸引力, 发扬“一天也不 耽误, 一天也不懈急” 的精神, 适应当前 社会发展的快节奏, 在潜移默化中引领 员工和企业健康稳步发展。完善企业人 力资源管理制度, 坚持科学发展理念, 坚 持以人为本, 在招聘过程中, 不能简单的 追求最优秀的人才, 要寻受最适合的人 才、能和企业共同成长的人才。要在面 试中迅速对应聘者的综合学识、性格特 征、沟通交流能力等方面做出综合判断, 决定其是否能与企业文化相契合。良好 
的企业文化会对员工未来发展做出正确 的引导,一个忠诚员工留在企业的职业 生涯可能长达几十年, 因此, 为了更好的 吸引和留住人才, 就要为员工提供一个 健康舒适的工作环境, 营造愉快和谐的 工作氛围, 以此来加强员工对企业的归 属感, 增加员工的责任感。自公司搬迁到 新办公区域后, 办公环境及各项设施不 断完善, 办公智能化、系统化, 办公流程 不断优化, 使得工作开展更加顺利。公司 党委、团委及工会定期组织员工参加集 体活动, 在新办公区设置健身器材并配 有淋浴设施, 举办技能知识竞赛、辩论 赛、乒乓球、篮球比赛, 定期为员工播 放电影等活动, 极大地丰富了员工的业 余生活、增进员工间交流、增强了企业 凝聚力, 在单位内部形成积极向上的良 好氛围, 工会在员工过生日的当月送上 生日贺卡和蛋糕, 让员工感受到家的温 暖, 极大程度地满足了员工的归属和爱 的需要。

\section{3 制定合理的职业生涯规划及} 人才激励机制,满足员工的尊重需要 和自我实现需要

对于有抱负、有理想的优秀人才, 企业会提供足够的晋升空间, 并制定合 理的职业生涯规划, 使员工的性格、潜 能、天赋得到充分的挖掘和认可, 做出准 确的职业定位, 明确发展方向, 并为他们 提供展示自我的平台, 让员工看到未来 的发展前景, 增强对企业的责任感和依 赖感, 有效防止企业培养的技术骨干流 失, 减少企业的招聘成本。同时优化人才
激励机制, 强调物质与精神激励双管齐 下, 鼓励员工参与科技创新研发、优质工 程建设、职业资格证书考取等, 制定相应 的现金激励政策, 增强员工不断进步的 动力, 以求企业与职工的共同发展, 增强 员工满意度, 达到双赢的效果, 同时每年 开展各项评优活动, 对在各方面表现突 出的员工授予荣誉称号, 树立为模范典 型予以宣传, 以发挥先进人物的示范引 领作用, 满足员工尊重的需要和自我实 现的需要。

为员工搭建晋升渠道, 加强公司后 备干部队伍建设, 加大人才培养力度。切 实规范干部选拔任用机制, 建设一支德 才兼备、结构合理的高素质高质量的中 层后备干部队伍, 经过层层选拔与考核, 选择品行兼优的员工进入公司重点培养 团队, 后备干部库实行动态化管理, 每年 根据员工综合能力进行淘汰和增补。人 才培养方面, 在原有员工安全、质量、专 业知识、法律知识等入职培训基础上加 入生产知识学习及现场工作实习等形式, 让新入职员工能在最短时间内对未来工 作有基本了解, 以便更快进入工作角色。 同时, 丰富培训形式及培训内容, 采用线 上培训、视频培训等方式, 加入管理能力 培训、技术能力培训、执业证书培训等, 让管理工作人才及专业技术人才能在工 作之余有选择性的学习各类课程, 提升 自己的管理能力、技术能力和综合素质 水平, 从而让培训工作达到更好的效果。

另外, 为了激发员工不断在自我完 善中提高工作水平、增强应对各种复杂
问题的工作能力, 企业一直摸索实践和 推行人员轮岗交流工作, 有效地改善了 机关部门人员长期从事相同工作而产生 的惰性思维和不良情绪, 使员工对公司 业务有更深层次的了解, 促进了在岗位 交流中不断提高综合素质、管理水平和 业务能力, 而专业技术人员的交流也会 提高员工技术水平、激发创造能力, 这项 工作在实践中收到了良好的效果。

2020 年是不平凡的一年, 由于新冠 肺炎疫情肆虐, 今年的企业和毕业生都 面临着巨大挑战, 作为有责任、有担当的 国有企业, 主动担起社会责任, 响应国家 号召, 加大人才引进力度、安置力度, 承 担社会责任, 在疫情期间, 最大限度的 保证员工利益, 作员工最坚强的后盾保 证, 夯实企业长远发展基础。一个企业 要在未来市场竞争中获得持续的竞争 优势, 必须具备管理上的创新精神。招 聘工作的有效实施, 不仅能带来支撑企 业未来可持续发展的人才资源, 有效实 施人力资源管理的变革与创新还会激 发员工潜在能力、企业特殊技能, 只有 这样的企业才最有可能获得可持续发 展和未来的成功。

\section{[参考文献]}

[1]人力资源管理专业知识与实务 (中级).人力资源社会保障部人事考试中 心 $[M]$. 中国人事出版社,2015.

[2]陈欣欣.马斯洛层次需求理论在 企业招聘中的应用 [M]. 商,2015(41):28，

[3]缪泉.招聘与录用 [M].北京: 中国 人民大学出版社,2004. 